\title{
Study of Parasitic Effect of Dactylogyrus sp. on Indian Major Carps of Pond Culture in Darbhanga
}

\author{
Priyanka Kumari* and M. M. R. Nomani \\ Department of Zoology, MLSM College, LNMU, Darbhanga, Bihar, India \\ *Corresponding author
}

\section{A B S T R A C T}

Keywords

Dactylogyrus, histopathology, parasitic, secondary lamellar epithelium, Indian major carps, necrosis

Article Info

Accepted:

12 May 2021

Available Online:

10 June 2021
The current study examines the parasitic effects of Dactylogyrus sp. on IMC. Only symptomatic and moribund samples of diseased fishes comprised of fingerlings and adults of Indian major carps were collected for experiments. Diseased fish showed significant behaviour changes like partial suffocation, lethargic swimming behaviour and their gills were very pale in colour and had haemorrhagic and inflamed areas at the sites of parasite attachments. Photomicrographs of the most characteristic regions of histopathological lesions in the stained tissues of diseased fish samples were taken. The main histopathological lesions and changes were seen in the gills where the parasites were found attached to the lamellar tissues causing local erosions of the epithelium. Hyperplasia of the secondary lamellar epithelium and fusion of adjacent secondary lamellae were the significant tissue level reactions caused by the parasites. No changes were noticed in other organs of the affected fishes. In severe infestations the fishes showed growth retardation. The histopathological analysis for parasites in fish would be useful tool for fish health monitoring. Fingerlings and adults of Catla were found highly susceptible to this disease than other IMC.

\section{Introduction}

In most of the fish farms, it was observed that among all fish pathogens, parasitic infestation has been the major cause of concern because of high morbidity and slow growth rate. These parasites were difficult to be removed from the culture system, causing significant setback to freshwater aquaculture. Under poor water quality conditions or stressful environment, these parasites multiply rapidly there by affecting fishes with high morbidity (Mishra, et al., 2017).

Dactylogyrosis is a disease caused by the monogenetic trematode, Dactylogyrus sp. was found to cause severe damage in the gills of the highly affected fishes. Adults of these parasites were found attached to the host's gill tissues by a characteristic structure having a 
row of hooks and sometimes suckers as well. Ozturk and Altunel (2006) reported that the abundance of $D$. difformis infection was higher in younger fish than in older fish.

Monogenean species are well known for their high degree of host specificity (Jarkovsky et al., 2004). The monogeneans are typically and often economically important ectoparasites of the skin or gills of fish. They are attached to the host surface by a characteristic opisthaptor which is species-specific and has hooks and hooklets (order Monopisthocotylea) or clamps (order Polyopisthocotylea). The monogenea are hermaphroditic flatworms and mainly cytoparasites of aquatic vertebrates.

They are often found in the gills or on the external surface of the fish. The genus Dactylogyrus is the largest helminth genus, with more than 900 species and generally has high host specificity. Most Dactylogyrus species parasitize cyprinids although certain species are adapted to the more advanced fish families.

It is essential therefore, to obtain timely and precise diagnosis of any fish disease outbreak in culture fishery operations. Throughout visual examination for external signs of the disease at the pond site should be followed by detailed Pathomorphological, Pathoanatomical and microscopical, examinations of squas and permanent stained preparations of the tissue samples of diseased fishes in the laboratory (Ramudu K R, Dash G, Abraham T., 2013). Disease diagnosis also require analysis of water and soil sample from the ponds from where diseased dish samples are collected for diagnostic purposes.

It is important to mention here that the parasitic infestations are reportedly playing a major role in disease occurrences $(78 \%)$ in Indian freshwater aquaculture. There are around $21 \%$ production loss due to diseases, poor farm management practices and impaired growth. So the objectives of the present study were to isolate, identify and Dactylogyrus sp. infestation in Indian major carps.

\section{Materials and Methods}

Frequent incidences of various naturally occurring diseases were recorded in the cultivated ponds/tanks/hatcheries in Darbhanga's various State Govt. ponds and also private fish culturists during the period of observation.

Collected samples were comprised of fingerlings and adults of Indian major carps in most of the occasions. Only symptomatic and moribund samples of diseased fishes were collected and were brought to the laboratory for patho-morphological and patho-anatomical examinations. Patho-morphological examination was comprised of identifying and locating any visible external lesions, erosions, haemorrhages etc. and formation of cysts/spores/patches on body surfaces, gills and fins and making and examining smear preparations from affected sites of fins, skin and gills. Also, in certain parts of the body, squas preparations of these spores/cysts in wet and permanent forms were made and examined under the microscope for detecting aetiological agents. Patho-anatomical examination was then carried out for finding any visible lesions/inflammations in internal organs.

Small bits of tissues (3-4 mm thick) from the vital organs like skin, gills and intestine etc. of moribund or freshly killed diseased fish samples were collected and fixed in ten percent Neutral Buffered Formalin for 18-24 hours. It was prepared by dissolving $4 \mathrm{gm}$ of sodium dihydrogen phosphate and $6.5 \mathrm{gm}$ of Disodium hydrogen phosphate in $900 \mathrm{ml}$ of distilled water. $100 \mathrm{ml}$ of formaldehyde was then added and the fixative was ready for use. 
Fixed tissue samples were then processed and paraffin embedded blocks of all the tissues were prepared using the standard histological methods (Luna, 1968). Calcified tissues like skin and gills were decalcified in ten percent Nitric Acid which helped in getting perfect and unbroken serial sections of these tissues during microtomy. Tissue blocks were cut into serial sections (5-7 thick) by a rotary microtome. For routine staining of the histological sections, Ehrlich's Haematoxylin (H.) and alcoholic Eosin (E.) stains were prepared and used according to Luna (1968). Photomicrographs of the most characteristic regions of histopathological lesions in the stained tissues of diseased fish samples were taken.

\section{Results and Discussion}

This disease has been found to occur predominantly in the nursery and rearing ponds and also in the large fish culture ponds. Frequent mass mortalities of fish in the rearing and stocking ponds due to this disease have been observed. The disease is caused by a monogenetic Trematode, Dactylogyrus sp. which attracted particularly the gills of the fishes. Dactylogyrus sp. has hooks to attached with host (Figure.1).

\section{Fish Species affected}

Fingerlings, juveniles and adults of Labeo rohita, Catla Catla, and Cirrhinus mrigala have been found to be affected by this disease. Epizootic conditions due to this parasitic infestation in the rearing and large fish culture ponds have been recorded particularly in Indian major carps causing mass mortalities of these fishes.

\section{Clinical Symptoms and Gross pathology}

Highly affected fishes showed growth retardation, weight loss. partial suffocation, lethargic swimming behaviour, loss of appetite and tendency to take shelter near pond margin. Gills of fishes became very pale in colour and showed haemorrhagic and inflamed areas where the parasites got attached and had excess secretion of mucus. Histopathological examination of the gills of Labeo rohita infected by monogenetic parasites (Figures.2). Squas preparation of a portion of the affected gills showed the parasites attached to the gill tissue which confirmed like kidney, liver, spleen and intestine did not show significant gross pathology.

\section{Histopathlogy}

Large numbers of the parasites were seen attached to the secondary lamellar tissue of the highly affected catla samples examined (Figure.3,4). Significant histopathological changes in the gill tissue was the excessive proliferation of secondary lamellar epithelial cells due parasites. Although there was local tissue erosion at the site of parasite attached (Figure-3). Extreme hyperplastic condition was noticed in the Secondary lamellar epithelium in the adjacent regions (Figure-4). Also multi-focal haemorrhagic areas were seen in the primary lamellae in certain Zones of the gill Section (Figure.3). Excessive proliferation of the secondary lamellar epithelium due to hyperplasia led to the fusion of adjacent lamellae blocking or reducing the flow of water between the lamellae. In certain regions (Figure.4). where the parasites were found in abundant numbers in the gills, the extent of hyperplasia of secondary lamellar epithelium and the degree of fusion of adjacent lamellae were such that the secondary gills lamellae lost their identity totally and the whole gills appeared like slender road with only the showed degenerative changes and there were multi-focal haemorrhagic areas in the cartilage. Other vital organs of the affected samples did not show any histopathological changes. 


\section{Diagnostic histopathological lesions identified}

Detection of the parasites in the squas preparation of the gill of the affected fishes helped in the diagnosis of the disease. The main histopathological lesion were seen in the gills where the parasites were found attached to the secondary lamellar epithelium and fusion of adjacent gill lamellae were the tissue level reactions caused by the parasites.

This disease caused by the monogenetic trematode, Dactylogyrus $s p$. was found to cause severe damage in the gills of the highly affected fishes. Adults of these parasites were found attached to the host's gill tissues by a characteristic structure having a row of hooks and sometimes suckers as well. These hooks caused much damage to the gill tissue by penetrating through it. When large numbers of parasites were found attached to the gill, they caused extensive damage and trauma which made portals of entry for opportunistic invaders which in turn might caused further damage to the host. Bauer et al., (1973) described Dactylogyrus vastator as the most dangerous parasite of carp fry in the carp culture of warmer climates such as those of lsrael and southern USSR. Paperna (1964) reported on the adaptation of Dactylogyrus extensus to the iconological conditions of artificial ponds in lsrael and its pathogenic potentials. Ozturk and Altunel (2006) reported that the abundance of $D$. difformis infection was higher in younger fish than in older fish. D. sahuensis is a scarce Dactylogyrus species among dactylogyrids, which infect common carp. The species has special pathogenic effects on the gills of fish (Jalali and Barzegar, 2005). Grass carp is readily infected by several monogeneans, among them $D$. lamellatus is the most harmful parasite which is now spread throughout the country and causes high mortality in fingerlings, (Jalali and Molnar, 1990). Common carps occurring in freshwaters of Iran were infected with five species of Dactylogyrus then it was found that host specific infection while common carps living in Caspian sea were infected only with two species, D. extensus and D. anchoratus (Jalali, et al., 1998, 2009). In general, species of Dactylogyrus show seasonal changes in their population dynamics. The increased Dactylogyrus infection in spring and summer agree with other studies, which report the favorable temperature of the warmer season on reproduction (Stojanovsky et al., 2010; Koyun, 2011; Turgut et al., 2011). Mashego and Matlou (2018) reported a new Dactylogyrus species from Enteromius mattozi, Cyprinidae, at Piet Gouws Dam, South Africa. These observations also corroborated the results of the present studies.

Small $(1 \mathrm{~cm}-10 \mathrm{~cm})$ and medium $(10.5-30 \mathrm{~cm})$ sized fishes were more susceptible to Dactylogyrus sp., which corroborated with the result of Golder, et al., (1987). He had observed that among the different size groups of fishes, the prevalence was highest in medium length groups, abundance and mean density was highest in smaller length groups. The reason for it is that small and medium size fishes have less immune power compared to large size fishes $(30.5 \mathrm{~cm}-45 \mathrm{~cm})$.

Prevalence and severity of monogenean parasites were more during August, September and October months. During the study highest infestation with Dactylogyrus sp. in the month of August (83.45\%), lowest (4.5\%) in the month of June was recorded. The maximum prevalence of monogenean parasites were recorded in the month of August and the minimum in June (E. Soylu, B. Rüzgar and M. Soylu, 2010). In December month again prevalence of monogenean parasites was increased due to sudden changes of temperature. Poor water quality, health management, irregular feeding practices and host specificity and preference are some of the 
key factors that lead to stressful conditions and subsequent parasitic infection of the host organism (Kurva and Gadadhar, 2013). Similar observations were found in our present study.

Large numbers of Dactylogyrus parasites altered the gill structure and its function. Hyperplastic changes of the gill lamellar epithelium were noticed at the surface much away from the site of attachment of the parasites. Telangiectatic gill lamellae were also frequently encountered near the regions of parasite attachment. Local tissue erosion at the sites of parasite attachments was accompanied by vigorous peripheral proliferations of lamellar epithelium. Hypersecretion of mucus on the affected gills might have seriously affected the respiratory functions of the gills. In acute cases the colour of gills faded away and the general effects of these parasites on the host fish included growth retardation, weight loss, altered behavioral patterns, erratic and lethargic swimming, loss of appetite and congregations near pond sides.

Histopathological changes and the extent of tissue damage on the gills of the highly affected fishes examined for the studies were quite characteristic. Large numbers of the Dactylogyrus sp. parasites were found lodged and attached to the secondary lamellar tissue and induced excessive proliferation of the secondary lamellar epithelium due to hyperplasia around the sites of parasite attachments.

At the sites of parasite attachment, the lamellar epithelium and the capillaries were found eroded leading to the destruction of the gill tissue. Also, at the places where the parasite concentration was more, multi-focal haemorrhagic areas were noticed in the primary lamellar tissues in certain zones of the gill sections. Fusion of adjacent secondary lamellae resulting from hyperplasia of the secondary lamellar epithelium due to the attachment of the parasites in the gills led to blocking or reducing the flow of water between the gill lamellae, reducing the flow of water between the gill lamellae. This resulted in asphyxia conditions in the affected fishes leading to mortality. Another significant histopathological change observed in certain regions of the gill section of the highly affected samples was the extreme hyperplasia of the secondary lamellar epithelium which rendered the whole gill look like slender rods with the cartilage cells placed centrally. The cartilage cells showed necrotic changes and had multi-focal haemorrhagic areas in the cartilaginous tissue of the affected gills. Molnar (1972) described histopathological changes due to gill parasitosis of the grass carp caused by the trematode, Dactylogyrus lamellatus. Establishment of the parasite gave rise to local and general lesions. The local lesions included erosions, endothelial impairment and minor areas of cell degeneration around the sites of parasite attachment.

The general gill lesions included degeneration, tissue damage, haemorrhages, necrosis, and atrophy and cell proliferation. Khalil, et al., (2018) reported that Gills of infected sea bass and sea bream infected by Dactylogyrus sp. showing parasitic infestation at the gill's tip, granulomatous inflammation also showing parasitic infestation, embedded trophonts, at the gill's tip also, and showing parasitic infestation, embedded trophonts. The results of the present histopathological studies on Dactylogyrosis of Indian major carps are in perfect agreement with those of Molnar (1972) and Khalil (2018). In Dactylogyrosis the branchial epithelium is destroyed at places of attachment of the worms, and these follow tissue fissures. 
Fig.1 Dactylgyrous sp. with distinct marginal hooks (arrow) (Wetmount, 100x)

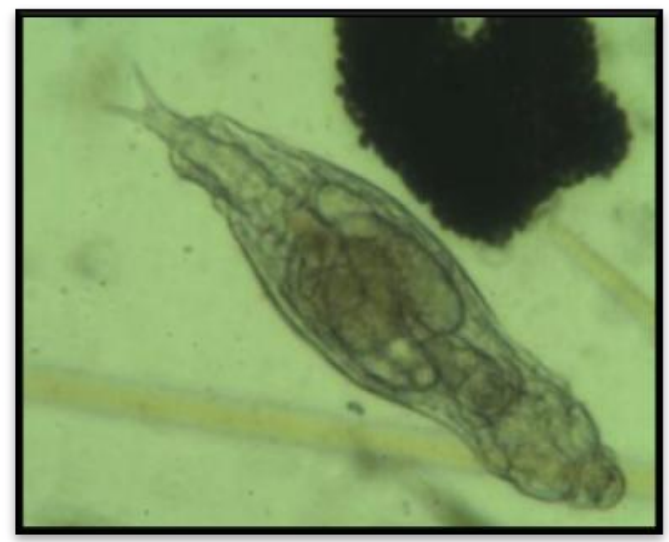

Fig.2 Photograph the infected gills of Catla catla.

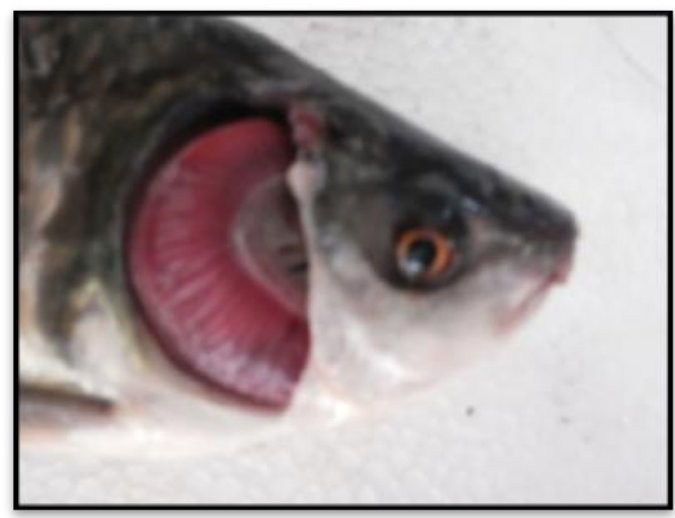

Fig.3 Gill of Catla catla (Ham) infected with Dactylogyrus sp. showing the parasites (P) attached to the secondary lamellae causing lamellar hyperplasia $(\mathrm{LH})$ and haemorrhages $(\mathrm{H})$ in the primary lamellae. H. \& E., X 200.

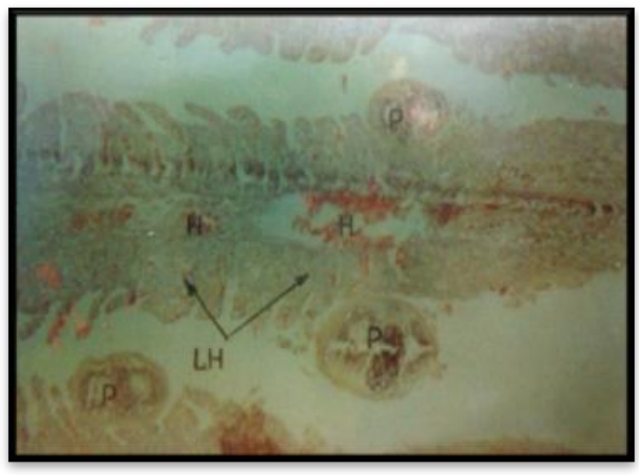


Fig.4 Gill of Catla catla (Ham) with Dactylogyrus sp. infection showing extremely hyperplastic secondary lamellae leading to lamellar fusion (LF) due to parasites. Cason stain, X 200.

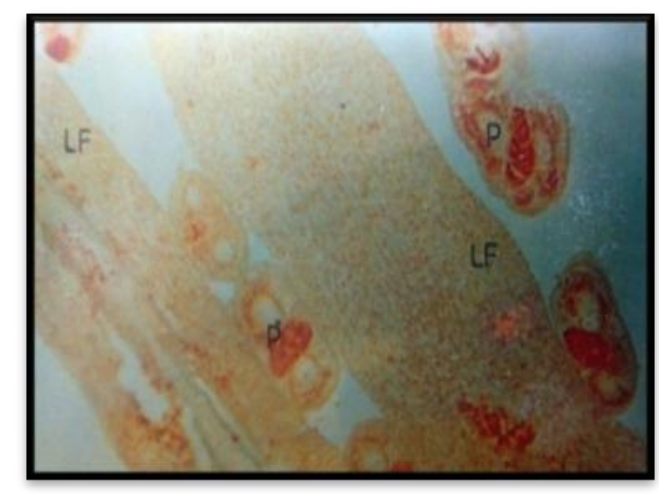

Proliferation of the branchial epithelium is stimulated by mechanical and according to Bauer et al., (1954) possibly also by chemical destruction. This leads to the formation of long thin processes or prolongations of adjoining gill filaments and lamellae. The epithelial cells in the process are multilayered. According to Scerbina (1973) the tissue proliferations appear when the young fish have overcome the acute form of disease. The pathogenic significance of the change over from unilayered to multi-layered branchial epithelium lies in the fact that the capillaries are surrounded by several layers of cells and the gaseous exchange becomes difficult. Besides, the structure of capillaries is also altered. Due to the disturbance in the blood supply, the tissues of the gill filaments are no longer adequately nourished. The result is that the epithelial processes gradually decay and drop off.

The destruction of the gills collectively affects the respiratory exchange in the diseased fish. According to Uspenskaja (1961) diseased fish consume considerably less oxygen than the healthy ones. Paperna (1964b) studied in detail the host reaction of infestation of carp with Dactylogyrus parasites. These observations also corroborated the results of the present studies. In Indian published literatures on Dactylogyrosis of Indian major carps are those of Tripathi (1957); Hora and Pillay (1962); Gopalakrishnan, (1963, 1964,1966); Ramkrishna et al., (1990); Rao et al., (1990); Seenappa and Devraj (1990); and Kumar \& Dey (1991). All these studies are related to taxonomy, biology and certain aspects of control measures for Dactylogyrus parasites. The present study on the histopathology of Dactylogyrosis in the Indian major carp is a new addition to the knowledge on this important parasitic disease of fish in India.

\section{Control measure}

The disease could be effectively controlled in the affected ponds by adopting any one of the following treatment methods such as alternate baths in 1 : 2000 acetic acid solution and 2\% sodium chloride solution; Dip in 5\% common salt solution and 1 : 5000 formalin for five minutes; only one application of $25 \mathrm{ppm}$ formalin solution in ponds; $0.5 \mathrm{ppm}$ potassium permanganate solution in ponds and $0.25 \mathrm{ppm}$ malathion in pond. However, malathion has been observed to give comparatively better control against the parasites than the other chemicals. Formalin, has been approved by the US FDA for use in aquaculture, but when applied to ponds, can kill phytoplankton and cause oxygen depletion. Similarly, Formalin apparently reacts with ammonia to form hex- 
amethylenetriamine and possibly formamide, a toxic substance to aquatic ecosystem. These chemicals are used mostly in hatcheries and, to a limited extent, in grow-out ponds (Pathak, et al., 2000).

The main histopathological lesions and changes were seen in the gills where the parasites were found attached to the lamellar tissues causing local erosions of the epithelium. Hyperplasia of the secondary lamellar epithelium and fusion of adjacent secondary lamellae were the significant tissue level reactions caused by the parasites. No changes were noticed in other organs of the affected fishes. In severe infestations the fishes showed growth retardation. Partial suffocation, lethargic swimming behaviour and their gills were very pale in colour and had haemorrhagic and inflamed areas at the sites of parasite attachments.

The findings accomplished that disease, Dactylogyrosis caused by the monogenetic trematode, Dactylogyrus sp. was observed predominantly in the nursery and rearing ponds. Fingerlings and adults of Catla were found highly susceptible to this disease than other IMC. The infection may visualize with necked eyes and need to manage promptly to secure the health of Indian major carps.

\section{Acknowledgement}

The authors are thankful to the Department of Zoology, MLSM College, LNM University, Darbhanga, for the provision of laboratory facilities used in this study.

\section{References}

Bauer, O. N., V. A. Musselius and Y. A. strelkov, 1973 : Diseases of pond fishes, Jersulem. Israel program for Scientific Translations.

Bauer, O. N. and N. P. Nikol `skaja, 1954 : Dactylogyrus solidus Achm., ego biologija, razvite i rhybochzjajstvennoe znacenie. Trudy Problemn, i Tematic. Sovesc. Zool. Inst. AN SSSR, 4 : $99-$ 109.

Bisset, K. A. 1946 : The effects of temperature on non - specific infection of fish. J. Path. Bact. $58: 251$ - 258.

Chaicharn, A. and W. L. Bullock 1967 : The histopathology of Acanthocephalan infection in suckers with observations on the intestinal histology of two species of catastomid fishes. Acta. Zoologica 48 : $19-41$.

Chniabut, S. and C. Limsuan 1983a : Histopatholgical changes in some freshwater fishes found during the disease outbreak : 1982 - 1983. Thai. Fish Gaz. 36 : 281 -298 (In Thai, English abstract).

Chinabut, S. and C. Limsuan, 1983 b : Histopathology of Waking catfish (Clarias batrachus) infected by Aeromonas hydrophila. Dep. Fish. Thailand. Natl. Inl. Fish Inst. Tech. Pap. No.24, 8 p (In Thai, English abstract).

Golder M. I., K. J. Chndra and A. K. A. Rahman. 1987 : Helminth parasitism in Nandus nandus (Hamilton).Bangladesh Journal of Fisheries. 10: 11-12.

Gopalakrishnan, V. 1963 : Controlling pests and diseases of cultured fishes. Indian Livestock. 1 (1) : $51-54$.

Gopalakrishnan, V. 1964 : Recent developments in the prevention and control of fishes cultured in Indian Waters. Proc. Zool. Soc. Bengal, 17 : 95 - 100.

Gopalakrishnan, V., 1966 : Diseases and parasites of fishes in warm water ponds in Asia and far - east. proc. FAO. World Symp. on warm water pond fish culture, ROME, 18-25, May, FR.IX/R - A. 25. 1966.

Hassan, N., 2005 : Study on some aspects of parasitic diseases of some fresh water fishes. Ph. D thesis, L.N.M.Univ., Darbhanga.

Hora, S. L. and T. V. R. Pillay, 1962 : Handbook on fish culture in the Indo pacific Region. F AO : Fish. Biol. Tech. 
$14: 1-204$.

Jalali, B., 1998: Parasites and parasitic diseases of freshwater fishes of Iran. 1st Edn., Aquaculture Deputy, Fisheries Company of Iran. P: 564 (In Persian).

Jalali, B and Barzegar, M., 2005: Dactylogyrus spp. (Monogenea: Dactylogyridae) in common carp (Cyprinus carpio L, 1750) of fresh water fishes of Iran and description of the pathogenicity of $\mathrm{D}$. sahuensis Ling, 1985. J. Agric. Sci. Technol., 7: 9-16.

Jalali, B and Molnar, K., 1990: Occurrence of monogeneans on freshwater fishes in Iran: Dactylogyrus spp. on cultured fish. Acta Vet. Hung., 38: 239-242.

Jarkovsky, J., Morand, S., Simkova, A., Gelnar, M. 2004: Reproductive barriers of congeneric monogenean parasites (Dactylogyrus: Monogenea): attachment apparatus morphology or copulatory organ incompatibility, Parasitology Research, 92(2): 95-105.

Kabata, Z. 1985 : Parasites and disease of fish cultured in the tropics. London \& Philadelphia: Taylor \& Francis (Publishers.

Khalil R, Medhat S S, Hanan A G, Khallaf M, Sherif E S. 2018 : Seasonal Parasitic Infestations and their Close Relationship to Immune Suppression in Cultured Sea Bass (Dicentrarchus labrax 1) and Sea Bream (Sparus auratus). Biomed J Sci \& Tech Res 6(4)- 2018. BJSTR. MS.ID.001376. DOI: $\quad 10.26717 /$ BJSTR.2018.06.001376.

Krkošek, M.; Connors, B. M.; Ford, H.; Peacock, S.; Mages, P.; Ford, J. S.; Morton, A.; Volpe, J. P.; Hilborn, R.; Dill, L. M. \& Lewis, M. A. 2011: Fish farms, parasites, and predators: implications for salmon population dynamics. Ecological Applications, Vol.21, pp. 897-914.

Koyun, M. 2011: Seasonal distribution and ecology of some Dactylogyrus species infecting Alburnus alburnus and Carassius carassius (Osteichthyes: Cyprinidae) from Porsuk River, Turkey.
African Journal of Biotechnology, 10 (7): 1154-1159.

Kumar, D. and R. K. Dey, 1991 : Fish diseases in India, Aquaculture Productivity. Ed. V. R. P. Sinha H. C. Srivastava, Oxford \& IBH publishing Co., Pvt. Ltd. pp. 315 -343 .

Kurva Raghu Ramudu and Gadadhar Dash 2013: Prevalence of Monogenean Parasites on Indian Major Carps in Bheries of West Bengal. International Journal of Chemical and Biochemical Sciences IJCBS, 4:13-21.

Luna, G. 1968 : Manual of histologic staining methods of the Amerd Forces Institute of Pathology, $3^{\text {rd }}$ Edition, McGrow -Hill Book Company, New York.

Mashego S. N., Matlou K. S. 2018 : A new Dactylogyrus species (Dactylogyridae: Monogenea) from Enteromius mattozi, Cyprinidae, at Piet Gouws Dam, South Africa. Afr Zool 53:107-111. https://doi.org/10.1080/15627020.2018.1 521301

Mishra S S, Das R, Choudhary P, Debbarma J, Sahoo S N, et al., 2017 : Prevalence of Fish and Shrimp Diseases and Use of Various Drugs and Chemicals in Indian Aquaculture for Disease Management. J Fish Aqua Dev: JFAD-129. DOI: 10.29011/JFAD-129. 100029

Mohamed Abdel-Meguid 2001 : Sensitivity of the monogenetic trematode Dactylogyrus lamellatus and the host grass carp Ctenopharyngodon idela to different concentrations of earthtec ${ }^{\mathrm{TM}}$ Egypt.J. Aquet. BioL \& Fish., VoLS, No. $2: 121-128$.

Molnar, K. 1972 : Studies on gill parasitosis of the grass crap (Ctenopharyngodon idella) caused by Dactylogyrus lamellatus Molnar, K. 1979. Gill sphaerosporosis in the common carp and grass carp. Acta. Veterinnaria. Academiae. Scientiarum Hungaricae 27 : $99-113$.

Ozturk, M. O. and Altunel, F. N. 2006 : Occurrence of Dactylogyrus infection linked to seasonal changes and host fish 
size on four cyprinid fishes in lake Manyas, Turkey. Acta Zoologica Academiae Scientiarum Hungaricae, 52 (4): 407-415.

Paperna, I., 1964a: Adaptation of Dactylogrus extensus (Mueller \& Van cleave, 1932), to ecological conditions of artifical ponds in Israel. J. parasit. 50 : 90 -93.

Paperna, I, 1964b: Host reaction to infestation of carp with Dactylogyrus vastator Nybelin, 1924, Monogenea. Bamidgeh. Bull. Fish. Cult. Israel 16 (4) : 129 141.

Pathak S C, Ghosh S K, Palanisamy K 2000 : The use of chemicals in aquaculture in India. In: J. R. Arthur, C. R. LavillaPitogo, \& R. P. Subasinghe (Eds.) Use of Chemicals in Aquaculture in Asia: Proceedings of the Meeting on the Use of Chemicals in Aquaculture in Asia 2022 May 1996, Tigbauan, Iloilo, Philippines: 87-112.

Ramudu K R, Dash G, Abraham T., 2013: Parasitic study of Cirrhinus mrigala (Hamilton, 1822) in Selected Districts of West Bengal, India. International Journal of Advanced Biotechnology and Research; 4:(4):419-436.

Rao, K. G., R. Ramkrishna and V. Rao, 1990: Observations on the prevelance of fish diseases in commercial farm ponds of Andhra Pradesh. Abstract. proc. $2^{\text {nd }}$ Indian Fisheries Forum May, 27 -31, 1990. Mangalore, Karnataka, India, pp. 118.
Rucker, R. R., H. E., Johnson and G. M. Kaydas, 1952 : An interim report on gill Disease. prog. Fish. Cult. 14 : 10.

Scerbina, A. K. 1973 : Bolezni Ryb, Kiev, Izd. Urozaj, $403 \mathrm{p}$.

Seenappa, D. and K. V. Devraj, 1990 : parasitic infestations on younger stages of cultivable carps in fish seed farms. Abstract. proc. $2^{\text {nd }}$ Indian Fisheries Forum. May, 27 -1, 1990, mangalore, Karnataka, India. pp. 121.

Stojanovski, S., Hristovski, N., Cakic, P., Hristovski, M., Velkova Jordanoska, L. And Blazekovic, D. 2010: Biotechnol and Biotecnol EQ, Second Balkan Conference on Biology 21-23 May 2010, Plovdiv 623-627.

Tripathi, Y. R. 1957 : Monogenetic trematodes from fishes of India. Indian J. Helmint, $9(1 / 2): 1-149$.

Turgut, E., Ozgul, G. and Buhan, E. 2011: Seasonal changes of metazoan parasites in Capoeta tinca and Capoeta capoeta in Almus Dam Lake, Turkey. European Association of Fish Pathologist, 31 (1):23-30.

Uspenskaja, A. V. 1961: Vlijanie Dactylogyrus vastator Nybelin, 1924 (Monogenoidea : Dactylogyridae) na organizm Karpa. Zool. Zurn. Moscow. 40(1) : 7-12.

Verma, S. R. S. P., Gupta and M. P. Tuagi, 1975 : Studies on toxicity of lindane on Colisa fasciata (part I. TLM measurement and histopathological changes in certain tissues). Morphol. Jahrb. 121 (1) : 38-54.

\section{How to cite this article:}

Priyanka Kumari and Nomani, M. M. R. 2021. Study of Parasitic Effect of Dactylogyrus sp. on Indian Major Carps of Pond Culture in Darbhanga. Int.J.Curr.Microbiol.App.Sci. 10(06): 467476. doi: https://doi.org/10.20546/ijcmas.2021.1006.050 